Trakya Eğitim Dergisi

Cilt 9, Sayı 1

Ocak 2019, 108-124

Geliş Tarihi: 18.08.2018

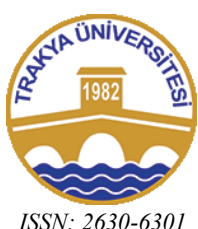

Doi: $10.24315 /$ tred. 454523

Araştırma Makalesi
Trakya Journal of Education

Volume 9, Issue 1

January 2019, 108-124

Yayına Kabul Tarihi: 16.01.2019

\title{
Öğretmenlerin Örgütsel Güven Algılarının Değişime İlişkin Tutumlarına Etkisi ${ }^{1}$ The Effect of Teachers' Perceptions of Organizational Trust on Their Attitudes towards Change
}

\section{Kazım ÇELIK' ${ }^{2}$ Muharrem GENCER ${ }^{3}$}

Öz: Araştırmada, öğretmenlerin örgütsel güven algılarının değişime ilişkin tutumlarına etkisini belirlemek amaçlanmıştır. İlişkisel tarama modelinde tasarlanan araştırmanın örneklemini, Burdur ili Yeşilova, Karamanlı ve Tefenni ilçelerinde görev yapan 315 öğretmen oluşturmaktadır. Veriler, Örgütsel Güven Ölçeği ve Değişme Tutum Ölçeği ile toplanmıştır. Verilerin analizinde bağımsız iki örneklem t-testi, tek yönlü varyans analizi ve çoklu regresyon analizi kullanılmıştır. Araştırmanın sonucunda öğretmenlerin örgütsel güven algılarının ve değişime ilişkin tutumlarının yüksek düzeyde olduğu, öğretmenlerin değişime ilişkin tutumlarının yaşa ve kıdeme göre farklılaştığı bulunmuştur. Yöneticiye güven, paydaşlara güven ve meslektaşlara güvenin değişime ilişkin tutumu pozitif yönde yordadığı saptanmıştır. Araştırmanın bulguları, ilgili alınyazın 1şı̆̆ında tartışılarak gelecekte yapılacak çalışmalar için çeşitli önerilerde bulunulmuştur.

Anahtar sözcükler: Örgütsel güven, değişim, algl, tutum.

\begin{abstract}
The purpose of this study is to determine the effect of teachers' perceptions of organizational trust on their attitudes towards change. The sample, which is designed in the relational survey model, consists of 315 teachers working in the districts of Yeşilova, Karamanlı and Tefenni in Burdur province. Data were collected by Organizational Trust Scale and Change Attitude Scale. Independent samples t-test, one-way variance analysis and multiple regression analysis were used in the analysis of the data. It was found out that teachers' perceptions of organizational trust and their attitudes towards change were at high level and teachers' attitudes towards change differed according to age and seniority. Besides, it was determined that trust in principal, clients and colleagues predicted the attitude towards change positively. The results were discussed in the light of relevant literature and various recommendations for future research were made.
\end{abstract}

Keywords: Organizational trust, change, perception, attitude

Cite this article as: 108-124.

Çelik, K., \& Gencer, M. (2019). Öğretmenlerin örgütsel güven algılarının değişime ilişkin tutumlarına etkisi. Trakya Eğitim Dergisi, 9(1),

\section{EXTENDED ABSTRACT}

\section{Introduction}

Organizations need a sense of trust that will strengthen their corporate commitment to enable employees to use their qualities and creativity. For this reason, the concept of organizational trust has recently taken an important status in all organizations worldwide (Halis, Gökgöz \& Yaşar, 2007). Trust, which is founded on the basis of employees' relations with each other and with the organization, Paliszkiewicz and Koohang (2013) have defined as an individual's belief and positive expectation for a situation or a person. Because of the fact that their input and output are human (Türker \& Çelik, 2018) trust has a more important position for schools that are educational organizations. Due to this, in the past few years, issues related to trust have been at the center of debates about the future of education (Louis, 2007). Hoy and Tschannen-Moren (2003) examined organizational trust in schools with trust in principal, colleagues and clients (parents and students) dimensions.

The concept of change, which has been effective since mankind's existence, is being felt more prominently in our time. Organizations have to adapt to changes and developments that are taking

\footnotetext{
${ }^{1}$ Bu çalışmanın bir kısmı 8-10 Haziran 2015 tarihinde gerçekleştirilen 2. Uluslar Arası Avrasya Eğitim Araştırmaları Kongresi'nde sözlü bildiri olarak sunulmuştur.

2 Doç. Dr., Pamukkale Üniversitesi, Eğitim Fakültesi, Eğitim Bilimleri Bölümü, Eğitim Yönetimi A.B.D., e-posta: kcelik@pau.edu.tr

${ }^{3}$ Dr., Milli Eğitim Bakanlığı, Burdur, e-posta: muharremgencer1978@hotmail.com
} 
place in order to survive and compete with other organizations. Organizational change can be described as a qualitative and quantitative differentiation, passing from an existing situation to a different one and an intervention from inside or outside over time (İlğan, 2007). As long as developments in the world continue technologically and scientifically, changes will continue to be made in schools the main task of which are to provide their outputs' adaptation to society and to raise individuals who can keep up with these developments. In order to succeed change initiatives in schools, teachers need to develop positive attitudes towards change in trust-based work environments. For this reason, the concept of trust that takes part in social network of schools has been the subject of many researches in recent years (Bökeoğlu \& Yılmaz, 2008; Cerit, 2009; Çağlar, 2011; Hoy \& DiPaola, 2008; İşcan \& Sayın, 2010; Jiang, Gollan \& Brooks, 2017; Memduhoğlu \& Zengin, 2011; Nedkovski, Guerci, Battisti \& Siletti, 2017; Taşkın \& Dilek, 2010; Yılmaz, 2009). However, no research has been found in the literature on the concept of organizational trust and change discussed together. In this research, in order to contribute to the related literature, it was aimed to determine the levels of teachers' perceptions of organizational trust and their attitudes towards change and the effect of organizational trust on attitude towards change.

\section{Method}

This research, which examines the effect of teachers' organizational trust perceptions on change attitudes, is designed in relational survey model. The sample of the research conducted in the districts of Yeşilova, Karamanlı and Tefenni in Burdur province in 2017-2018 academic year consists of 315 teachers. For the collection of the data, "Organizational Trust Scale" developed by Hoy and Tschannen-Moran (2003); adapted to Turkish by Özer, Demirtaş, Üstüner and Cömert (2006) and "Change Attitude Scale" developed by Tanriöğen (2000) were used. Descriptive analyses such as arithmetic mean, standard deviation, independent samples t-test and one-way variance analysis and stepwise multiple regression were used in the analysis of the data.

\section{Result and Discussion}

As a result of the research, it was reached that in their schools teachers trust principals the most and clients (students and parents) the least. Teachers' trust in principals is so important for the operation of schools. Because, teachers who trust principals can show more collaborative, selfsacrificing, and open-minded behavior. Although the quality of education is enhanced by cooperating with students and parents and the teachers who prepare students for life during the education process, teachers trust students and parents the least. Similarly in their studies, Ayık, Savaş and Çelikel (2014), Bökeoğlu and Yılmaz (2008), Ergün (2017), Tschannen-Moran (2001) reached the conclusion that teachers trust principals the most and clients the least. The perceptions of teachers towards organizational trust scale were collected at a high level. This result shows that teachers have a sense of trust in their schools. Similar to the study, Polat and Celep (2008) found out that teachers had a high level of trust. Research has also been found in the literature to reveal that teachers have trust at medium level (Bökeoğlu \& Y1lmaz, 2008; Kalayc1, 2007; Yıldız, 2013).

When the results of the teachers' attitudes towards organizational change and sub-dimensions are examined, it is seen that the highest average score belongs to cognitive dimension and the lowest average score belongs to psychomotor dimension. This result shows that psychomotor namely behavioral element of attitude has emerged as a result of cognitive and affective elements (İnceoğlu, 2010). Teachers' attitude towards overall organizational change scale is at high level. It can be said that towards change, which is considered as a natural and inevitable phenomenon in the schools (Beycioğlu \& Aslan, 2010), teachers have developed positive attitudes. Unlike this study, Kurşunoğlu and Tanriöğen (2006) reached the conclusion that teachers' attitudes towards organizational change were at medium level.

In the study, it has been found out that there is no significant difference between the teachers' perceptions of organizational trust according to gender, age, seniority and branches. According to this result, it can be said that variables taken into account do not affect teachers' perceptions of organizational trust. It was revealed that teachers' attitudes towards organizational change were not different according to their gender and branches, however they differed according to their age and seniority. The attitudes of 41 year old and older teachers towards change were found to be lower than the attitudes of 21-30 and 31-40 year old teachers. The reason why 41 and upper-age teachers' attitudes towards change was low that they do not want to change the habits and behaviors they have lived for a long time. Similarly, it has been found that attitudes of teachers with 10-19 years and 20 
years and up seniority towards change are lower than the attitudes of teachers with 1-9 years of seniority. According to this result, it can be said that teachers with low seniority may be more dynamic and enthusiastic, motivation levels of the teachers who have been in the profession for many years may decrease because of this, their attitudes towards change may have fallen.

In this study; trust in principals, colleagues, students and parents are significant predictors of teachers' attitudes towards change. In schools where trust, key element of intra-organizational relationships, is dominant (Krotand \& Lewicka, 2012) because teachers work more comfortable and dedicated, they may become more open to change in order to develop themselves and their institutions. As a result, in order for teachers to develop positive attitudes towards change and for change initiatives to achieve the desired results, it can be said that existence of a school culture based on trust plays a catalyst role.

\section{GİRIŞ}

Rekabet ortamının giderek arttı̆gı günümüzde, örgütler amaçlarını gerçekleştirebilmek için sahip oldukları maddi ve beşeri kaynakları en etkin biçimde kullanabilmeyi hedeflemektedirler (Çelik \& Tabancal1, 2012). Örgütlerde özellikle çalışanların, işe ait bilgi ve becerilerini kullanabilmesi için kurumsal bağlılığını pekiştirecek güven duygusuna ihtiyaç duyulmaktadır. Bu nedenle örgütsel güven, dünya çapındaki tüm örgütlerde son zamanlarda giderek önemi artan bir kavram haline gelmiştir (Halis, Gökgöz \& Yaşar, 2007). Çalışanların birbirleriyle ve örgütle ilişkilerinin temelini oluşturan güven, geniş boyutlu bir kavram olup, farklı bilimlere konu olmuştur.

İnsanlık tarihinin başlangıcından itibaren insan ilişkilerinin vazgeçilmez unsurları arasında yer alan güven kavramını Paliszkiewicz ve Koohang (2013), bireyin bir duruma veya karşısındaki kişiye inancı ve olumlu beklentisi olarak tanımlamışlardır. Bromiley ve Cummings (1996) güvenin; a) açıkça ya da örtük olarak başkaları için iyi niyete sahip olma b) her durumda dürüst olma c) firsat bulunsa bile başkalarından aşırı yarar sağlamaya çalışmamayı beraberinde getireceğini ifade etmişlerdir. Temelinde iyi niyetin ve yetkinliğin olduğu güven (Das \& Teng, 2001), örgütlerde verimliliği en üst düzeye taşımak için oluşturulması gereken yapı taşlarından biri olarak düşünülmektedir. $\mathrm{Bu}$ nedenle araştırmacılar tarafından örgütsel güvenle ilgili birçok tanımlama yapılmıştır. Örneğin Mishra (1996), örgütsel güveni örgütteki ilişki ve etkileşimlerde çalışanların birbirlerine açık, dürüst, ilgili, gerçekçi davranması ve temel amaç, norm ve değerlerden haberdar olma isteği; Gilbert ve Tang (1998) ise çalışandaki güven ve destek duygusu olarak tanımlamışlardır. Shockley-Zalabak, Ellis ve Winograd (2000) güvenilir örgüt yapısını, bireyin diğer çalışanların rolleri, ilişkileri, deneyimleri ve dayanışmalarındaki niyet ve davranışları hakkında pozitif beklentilere sahip olunan ortam olarak betimlemişlerdir.

Örgütün kendisi ve çalışanları amaçlarına ulaşmak noktasında birbirlerine ihtiyaç duyarlar. Örgütleri daha iyi bir konuma taşımada önemli sorumluluklar üstlenen yöneticiler ve örgüt çalışanları birbirlerinin ihtiyaçlarını karşıladıklarında aralarında güven duygusu oluşur. Özellikle örgüt uygulamalarının adaletli olması çalışanların örgüte ve yöneticilere duyduğu güveni artırır. Yapılan çalışmalar örgütsel adaletin güven ortamının sağlanmasında önemli etkiye sahip olduğunu göstermiştir (İşcan \& Sayın, 2010; Bidarian \& Jafari, 2012; Al-Abrrow, Shaker Ardakani, Harooni, 2013; Fischer, 2012; Yıldız, 2013; Aksoy, 2016). Örgütlerde güven ortamının oluşmas1 ise çalışanların örgütlerine duydukları bağlılığı (Taşkın \& Dilek, 2010; Candan, 2014; Iqbal \& Ahmad, 2016; Lashari, Moazzam, Salman \& Irfan, 2016), iş doyumlarını (Siddiqi \& Kharshiing, 2015; Çiçek \& Şahin Macit, 2016) ve iş performanslarını (Büte, 2011; Usikalu, Ogunleye \& Effiong, 2015) artırarak örgütsel verimliliğe önemli katkıda bulunur. Örgütlerin başarısı üzerinde önemli etkilere sahip olan güven konusunun giderek daha çok önem kazanmasıyla birlikte araştırmacılar örgütsel güven kavramı ile ilgili çalışmalar yapmışlar ve örgütsel güvenle ilgili çeşitli modeller kurmuşlardır. Mishra (1996) oluşturduğu güven modelinde yeterlik, açılık, ilgililik ve itimat edilirlik olarak dört farklı güven boyutunu tanımlamıştır. Shockley-Zalabak, Ellis ve Winograd (2000), Mishra'nın modeline özdeşleşme boyutunu eklemişlerdir. Bromiley ve Cummings (1996) ise geliştirdikleri örgütsel güven envanterinde güveni; duygusal, bilişsel ve niyetsel olarak sınıflandırmışlar ve örgütsel güvenin örgüt içinde ya da örgütler arasında işlem maliyetlerini azalttığını açıklamışlardır.

Tüm örgütlerin refahı için gerekli olan güven olgusu, temel girdi ve çıtıları insan olması nedeniyle eğitim örgütleri olan okullarda (Türker \& Çelik, 2018) daha önemli bir konumdadır. Okullarda güven ortamının sağlanması öğretmen profesyonelliğini (Tschannen-Moran, 2009) dolayısıyla akademik başarıyı (Goddard \& Salloum, 2009) artırarak kısa vadede okulu, uzun vadede 
okulla etkileşim halinde olan toplumu etkiler. Güven ortamı olmayan okullarda çalışanlar, daha çok kendilerini korumaya yönelik çabalar sergileyecekleri için eğitim-öğretimin amaçlarını aksatabilirler. $\mathrm{Bu}$ nedenle geçtiğimiz yıllarda güvenle ilişkili konular eğitimin geleceği hakkındaki tartışmaların merkezine oturmuştur (Louis, 2007). Örgütsel güven; çalışanların meslektaşlarına, yöneticilerine, örgüt yapısına, paydaşlarına vb. unsurlara duyduğu güven olarak sıralanabilir. Hoy ve TschannenMoren (2003) okullarda örgütsel güveni yöneticiye, meslektaşlara ve paydaşlara (veli ve öğrencilere) güven boyutları ile incelemişlerdir. Örgütün başat kaynağı olan çalışan ve yönetici arasındaki olumlu ilişkilerin temelini karşılıklı güven oluşturur. Çalışanlar yöneticilerine güvendiklerinde örgütün amaçlarını daha etkin gerçekleştirebilmek için çaba gösterirler (Whitener, Brodt, Korsgaard \& Werner, 2013). Çünkü yöneticiye güven, örgütsel verimlilik ve genel memnuniyet (Ellis \& ShockleyZalabak, 2001), örgütsel kimlik ve rol performansı (Schaubroeck, Peng \& Hannah, 2013) davranışlarını pozitif yönde etkiler. Benzer şekilde meslektaşlarına güven, çalışanları eylemlerinde adil davranmaya, işbirliğine, dostluk ve etkili iletişime, olumlu sosyal ağlara, destek duygusuna ve sosyo-duygusal memnuniyete yol açar (Ferres, Connell \& Travaglione, 2004). Ayrica Tan ve Lim (2009) çalışanların iş arkadaşlarına karşı hissettikleri güvenin örgüt içindeki bütün güveni etkilediğini ileri sürmüşlerdir. Eğitim örgütlerinde yönetici ve meslektaşlara güvenin yanı sıra öğretmenler eğitimin ortak hedeflerini başarmak için paydaşlarına yani öğrenci ve velilere güvenmek zorundadırlar. Öğrenciler ve öğretmenler arasındaki güvene dayalı ilişkiler öğrencilerin akademik başarısını beslemekte (Goddard, Tschannen-Moran \& Hoy, 2001) aynı zamanda okulların amaçlarına ulaşması için büyük rol oynamaktadır (Moore, 2010).

Birbirlerine ve işyerlerine güven duyan çalışanların oluşturduğu örgütler, yüksek güven duygusunun çok çeşitli kapsamdaki sosyal ilişki türlerinin ortaya çıkmasına olanak tanıması sebebiyle örgütsel değişime uyum açısından daha başarılıdırlar (Çağlar, 2011). İnsanlığın varoluşundan bu yana etkisini gösteren değişim kavramı, özellikle çağımızda daha belirgin olarak hissedilmektedir. Örgütler yaşamlarını sürdürebilmek için yaşanan değişim ve gelişmelere uyum sağlamak ve diğer örgütlerle rekabet etmek zorundadırlar. Çünkü örgütleri çevreden izole etmek mümkün olmadığı gibi, varlıklarını ve rekabet gücünü sürdürmek isteyen örgütlerin, iç ve dış çevredeki değişimleri görmezden gelmesi mümkün değildir (Genç, 2004)

Örgüt içindeki herhangi bir birimin davranışlarında, yapılarında, yöntemlerinde, amaçlarında ya da çıktılarında değişiklik yapma süreci olarak tanımlanan (Hanson, 1996) örgütsel değişim, zaman içerisinde içeriden ya da dişarıdan müdahale ile örgütün faaliyetlerinde ve yapısında meydana gelen farklılaşma olarak ifade edilebilir (İlğan, 2007). Değişim girişimleri etkili bir şekilde yönetilirse, örgütün başarısında büyük rol oynar. Hiçbir örgüt değişime engel olamayacağından, örgütlerde değişim arzusu katlanarak artmaktadır. Bunun için çalışanlar tarafindan değişimin gerekliliğinin bilinmesi ve değişim girişimleri için hazırlık yapılması gereklidir (Alwheeb \& Rea, 2017). Örgütleri değişime iten güçler dışsal ve içsel faktörler olmak üzere iki grupta sınıflandırılabilir. Dışsal faktörler, örgüt yönetiminin kontrolü dışında olan ekonomik, teknolojik ve sosyal güçleri içerir. İçsel faktörler ise örgüt içinde işleyen ve genellikle yönetimin kontrolü altındaki güçlerdir. İçsel güçler, örgüt içindeki süreç ve davranışsal sorunların varlığına işaret eder (Gibson, Ivancevich ve Donnelly, 1988). Sonucu ne olursa olsun, tüm değişim girişimlerinin amacı örgütü daha iyi noktaya taşımak ve buna bağlı olarak örgütün sürekliliğini sağlamaktır. Yapılan araştırmalar değişim girişimlerinin sınırlı oranda başarıya ulaştı̆̆ını göstermektedir (George, White \& Schlaffer, 2007). Örgütlerde değişim girişimlerinin başarısızlıkla sonuçlanmasında; yetersiz politika yapımı ve stratejik yönetim, mevcut örgütsel yapılar, örgütlerdeki güç ve politika, örgütsel kültürler, bireysel belirsizlikler ve değişime psikolojik direnç neden olabilir (Boonstra, 2004). Değişime direncin azaltılması, çalışanların örgütü değişime yönelten güçleri anlamasına bağlıdır (Walker, Armenakis \& Bernerth, 2007). Değişim zamanlarında, örgüt çalışanları değişimi benimserse ya da kendilerine fayda getireceğine inanırsa, değişime ilişkin olumlu tutum geliştirirler ve muhtemelen yeni çalışma sistemine hızla adapte olurlar. Aksine, değişime yönelik olumsuz tutumlar, tersine etki yaratabilir ve önerilen değişikliklere uyum sağlama olasılığını azaltabilir. Tutumlar, insanların çevrenin yeni yüzünü anlamalarına, her yeni öğeyi değer aktaran ve davranışa yön veren bir inanç seti içinde özümsemelerine yardımcı olur (Neiva, Ros \& Paz, 2005). Tutum, kişilerin kendilerine ya da çevresindeki herhangi bir nesne, konu ya da olaya ilişkin deneyim, bilgi, duygu ve güdülerine dayanarak örgütlediği bilişsel, duyuşsal ve psikomotor (davranışsal) ön eğilimidir. Bilişsel tutum; bireyin çevresindeki nesnelere, insanlara, olaylara veya herhangi bir duruma ilişkin olarak sahip olduğu her tür bilgisini, deneyimini, inancını ve düşüncesini içerir. Duyuşsal tutum; bireyin sahip olduğu bilgi, duyum ve deneyimlerini olumlu, olumsuz olaylarla, 
istenen ya da istenmeyen amaçlarla ilişkilendirmesidir. Psikomotor tutum ise bireyin davranış eğilimini yansıtır (İnceoğlu, 2010).

Dünyada var olan her şey sürekli bir değişim içinde yol alırken (Taş, 2009) toplumların değişmesinde ve gelişmesinde ayrıcalıklı bir rol üstlenen okullar da değişimden etkilenmişlerdir. Bu gelişmeler teknolojik ve bilimsel olarak devam ettiği sürece temel görevi çıktılarının topluma uyumunu sağlamak ve dünyadaki gelişmelere ayak uydurabilen bireyler yetiştirmek olan okullarda değişimler devam edecektir. Alanyazında eğitim kurumlarında değişim ile ilgili çok sayıda çalışmalar yapılmıştır (Aydoğan, 2007; Finch, 2002; Kurşunoğlu \& Tanrı̈̆ğen, 2006; Rubagiza, Umutoni \& Kaleeba, 2016; Taşdan, 2013; Vandeyar, 2017). Okulların değişimden en çok etkilenen ve değişimi en çok etkileyen öğesi öğretmenlerdir. Okul müdürlerinin iş ortamındaki uygulamalarına yönelik öğretmenlerden aldıkları geri bildirimleri birer gelişim firsatı olarak görüp değerlendirebilmeleri değişimin vazgeçilmez unsurudur (Tanrıöğen, Baştürk \& Başer, 2014). Değişim girişimlerinin başarı ile sonuçlanması için okul yöneticilerinin bu girişimleri etkili bir şekilde yönetebilmeleri ve öğretmenlerin güvene dayalı çalışma ortamlarında değişime ilişkin olumlu tutumlar geliştirmeleri gerekmektedir. Bu nedenle okulların sosyal ağının içinde yer alan güven kavramı, son yıllarda çok sayıdaki araştırmanın konusu olmuştur (Bökeoğlu \& Yılmaz, 2008; Cerit, 2009; Çağlar, 2011; Hoy \& DiPaola, 2008; İşcan \& Sayın, 2010; Jiang, Gollan \& Brooks, 2017; Memduhoğlu \& Zengin, 2011; Nedkovski, Guerci, Battisti \& Siletti, 2017; Taşkın \& Dilek, 2010; Yılmaz, 2009). Ancak alınyazında örgütsel güven ve değişim kavramlarının birlikte ele alındığı araştırmaya rastlanılamamıştır. İlgili literatüre katkıda bulunmak amacıyla bu araştırmada, öğretmenlerin örgütsel güven algıları ve değişime ilişkin tutumlarının düzeyleri ile örgütsel güvenin değişime ilişkin tutum üzerinde etkisinin olup olmadığının belirlenmesi amaçlanmıştır. Bu amaçla; araştırmada aşağıdaki soruların yanıtları aranmıştır:

•Öğretmenlerin örgütsel güven algıları ve değişime ilişkin tutumları hangi düzeydedir?

-Öğretmenlerin örgütsel güven algıları ve değişime ilişkin tutumları, demografik değişkenlerine göre (cinsiyet, yaş, mesleki kıdem, branş) değişmekte midir?

•Öğretmenlerin örgütsel güven algıları ile değişime ilişkin tutumları arasında anlamlı bir ilişki var midir?

• Örgütsel güven değişime ilişkin tutumları yordamakta mıdır?

\section{YÖNTEM}

\subsection{Araştırma Modeli}

Araştırma, ilişkisel tarama modelindedir. İlişkisel tarama modelleri, iki veya daha çok sayıda değişken arasındaki birlikte değişim varlığını veya derecesini belirlemeyi amaçlayan araştırma modelleridir (Karasar, 2017).

\subsection{Evren ve Örneklem}

Araştırmanın evrenini 2017-2018 eğitim-öğretim yılında Burdur ili Yeşilova, Karamanlı ve Tefenni ilçelerinde görev yapan 392 öğretmen oluşturmaktadır. Araştırmada basit seçkisiz örnekleme yoluyla seçilen ve gönüllülük esasına göre araştırmaya katılan 336 öğretmene ulaşılmıştır. Ancak kullanılabilir 315 ölçek analize dâhil edilmiştir. Araştırma kapsamındaki öğretmenlerin cinsiyet, yaş, kıdem ve branş değişkenlerine ilişkin bilgiler Tablo 1'de verilmiştir.

Tablo 1. Katılımciların demografik özellikleri

\begin{tabular}{llll}
\hline Değişkenler & & $\mathbf{N}$ & $\mathbf{\%}$ \\
\hline \multirow{2}{*}{ Cinsiyet } & Kadın & 160 & 50,8 \\
& Erkek & 155 & 49.2 \\
Yaş & $21-30$ yaş & 117 & 37.1 \\
& $31-40$ yaş & 143 & 45.4 \\
& 41 yaş ve üzeri & 55 & 17.5 \\
Kıdem & $1-10$ yıl & 195 & 61,9 \\
& $11-20$ yıl & 75 & 23.8 \\
& 21 yıl ve üzeri & 45 & 14.3 \\
\multirow{2}{*}{ Branş̧ } & Sınıf Öğretmeni & 74 & 23.5 \\
& Sayısal Ders Öğretmeni & 80 & 25.4 \\
& Sözel Ders Öğretmeni & 92 & 29.2 \\
& Diğer Branş Öğretmenleri & 69 & 21.9 \\
\hline
\end{tabular}




\subsection{Veri Toplama Araçları}

Çalışmanın gerektirdiği verileri toplamak amacıyla "Örgütsel Güven Ölçeği” ve "Değişme Tutum Ölçeği” kullanılmıştır.

Örgütsel Güven Ölçeği: Ölçek, Hoy ve Tschannen-Moran (2003) tarafindan geliştirilmiş; Özer, Demirtaş, Üstüner ve Cömert (2006) tarafından Türkçeye uyarlanmıştır. Ölçek; meslektaşlara güven, veli ve öğrencilere güven, yöneticiye güven olarak adlandırılan üç alt boyut ve 20 maddeden oluşmaktadır. Ölçek maddeleri, " 1 = Hiç Katılmıyorum" ile " 5 = Tamamen Katılıyorum" aralığında yanıtlanmıştır. Ölçekten alınan puanın artması öğretmenlerin örgütsel güven düzeylerinin artması anlamına gelmektedir. Uyarlama çalışmasında ölçeğin yapı geçerliği açımlayıcı faktör analizi ile sağlanmış, açıkladığı toplam varyans \%48.83 olarak bulunmuştur. Ölçeğin alt boyutlarının Cronbach alfa iç tutarlılık katsayılarının .70 ile .82 arasında değiştiği belirtilmiştir. Bu çalışmada ölçeğin geçerliği doğrulayıcı faktör analizi, güvenirliği ise Cronbach alfa katsayı değerleri ile incelenmiştir. Doğrulayıc1 faktör analizi sonucunda elde edilen uyum iyiliği değerlerinin $\left(\chi^{2} / \mathrm{sd}=2.78 \quad(\mathrm{p}<.01)\right.$, $\mathrm{GFI}=.88, \mathrm{AGFI}=.85, \mathrm{NFI}=.90, \mathrm{IFI}=.93, \mathrm{TLI}=.92, \mathrm{CFI}=.93, \mathrm{RMSEA}=.07)$ kabul edilebilir düzeyde olduğu söylenebilir (Hu ve Bentler, 1999; Schermelleh-Engel, Moosbrugger, \& Müller, 2003; Hooper, Coughlan \& Mullen, 2008). Ölçeğin Cronbach alfa değeri meslektaşlara güven boyutu için .93 veli ve öğrencilere güven boyutu için .86 , yöneticiye güven boyutu için .87 ve ölçeğin geneli için .93 olarak hesaplanmıştır. Yapılan analizler sonucunda Örgütsel Güven Ölçeği'nin üç boyutlu yapısının bu çalışma kapsamında geçerli ve güvenilir olduğu söylenebilir.

Değişme Tutum Ölçeği: Ölçek, öğretmenlerin değişmeye ilişkin tutumlarını ölçmek için Tanrı̈ğen (2000) tarafından geliştirilmiştir. 5'li likert tipinde tasarlanan ölçek; bilişsel, duyuşsal, psikomotor olmak üzere üç alt boyuttan oluşmaktadır. 18 maddeden oluşan ölçek maddeleri, " $1=$ Hiç Katılmıyorum" ile " $5=$ Tamamen Katılıyorum" aralığında yanıtlanmıştır. Ölçekten alınan puanın artması öğretmenlerin değişime ilişkin olumlu tutum geliştirdikleri anlamına gelmektedir. Ölçeğin yapı geçerliği açımlayıcı faktör analizi ile sağlanmıştır. Alt boyutların Cronbach alfa katsayıları .92 ile .97 aralığında değişmektedir. Bu çalışmada ölçeğin geçerliği doğrulayıcı faktör analizi, güvenirliği Cronbach alfa katsayı değerleri ile incelenmiştir. Doğrulayıcı faktör analizi sonucunda yapısal modelin uyum indekslerinin kabul edilebilir düzeyde olduğu görülmüştür $\left(\chi^{2} / \mathrm{sd}=3.74 \quad(\mathrm{p}<.01)\right.$, $\mathrm{GFI}=.86, \mathrm{NFI}=.90, \mathrm{IFI}=.92, \mathrm{TLI}=.90, \mathrm{CFI}=.92, \mathrm{RMSEA}=.09)$. Cronbach alfa katsay1ları ise bilişsel boyutta .88 , duyuşsal boyutta .92 , psikomotor boyutta .89 ve ölçeğin genelinde .96 olarak hesaplanmıştır. Dolayısıyla Değişme Tutum Ölçeği'nin üç boyutlu yapısının bu çalışma kapsamında geçerli ve güvenilir olduğu genel sonucuna ulaşı1mıştır.

\subsection{Verilerin Analizi}

Verilerin analizine geçilmeden önce katılımcılar tarafından doldurulan ölçekler kontrol edilmiş ve özensiz doldurulan formlar analize dâhil edilmemiştir. Kullanılabilir olarak belirlenen 327 ölçek formundan 7'si z değerlerine ( $\mathrm{z} \geq 3$ ), 5'i ise Mahalanobis uzaklığına bakılarak analiz dışında bırakılmıştır. Sonuç olarak 315 ölçek formu ile analizler gerçekleştirilmiştir.

Verilerin normallik dağılımı, değişkenlere ilişkin çarpıklık ve basıklık değerlerine göre belirlenmiş̧ir. Normal dağılıma sahip veri setinde çarpıklık ve basıklık değerlerinin -1 ile +1 arasında olması gerekir (Huck, 2008). Bu çalışmada çarpıklık değerlerinin .082 ile .729 arasında, basıklık değerlerinin .195 ile .974 arasında olduğu belirlenmiştir. Bu bulgular, verilere ilişkin normalliğin sağlandığını göstermektedir. Regresyon analizinin güvenirliğini sağlamak amacıyla yordayıcı değişkenler arasında çoklu bağlantılık olup olmadığı kontrol edilmiş̧ir. Bağımsız değiş̧kenler arasında ikili korelasyon analizi yapılmış ve korelasyon değerlerinin .70'in üzerinde olmadığ belirlenmiştir. Ayrıca yordayıcı değişkenlerin VIF değerleri 10'dan (en yüksek VIF değeri=2.1) ve CI değerleri 30'dan (en yüksek CI değeri=26.3) küçük olduğu için çoklu doğrusallık varsayımının karşılandığı görülmüştür (Büyüköztürk, 2017). Son olarak Durbin-Watson değeri 1.731 olarak hesaplandığ için hazırlanan modelde otokorelasyon olmadığı belirlenmiştir (Kalaycı, 2009).

Araştırmada, öğretmenlerin örgütsel güven algılarını ve değişmeye ilişkin tutum düzeylerini tespit etmek amacıyla betimleyici analizler yapılmıştır. Bulguların yorumlanmasında kullanılan ortalama aralıklar 1.00-1.80 çok düşük, 1.81-2.60 düşük, 2.61-3.40 orta, 3.41-4.20 yüksek ve 4.215.00 çok yüksek olarak yorumlanmıştır. Öğretmenlerin örgütsel güven algılarının ve değişmeye ilişkin tutumlarının cinsiyete, yaşa, kıdeme ve branşa göre karşılaştırılması bağımsız iki örneklem t-testi ve tek yönlü varyans analizi ile incelenmiştir. Regresyon analizine geçilmeden önce yordayan ve yordanan değişkenler arasındaki ilişkiler Pearson korelasyon analizi ile belirlenmiştir. Örgütsel 
güvenin; meslektaşlara güven, paydaşlara güven ve yöneticiye güven alt boyutlarının öğretmenlerin değişime ilişkin tutumlarına etkisi ise aşamalı çoklu regresyon kullanılarak analiz edilmiştir. Çalışmada test edilen regresyon modeli Şekil 1'de verilmiştir.

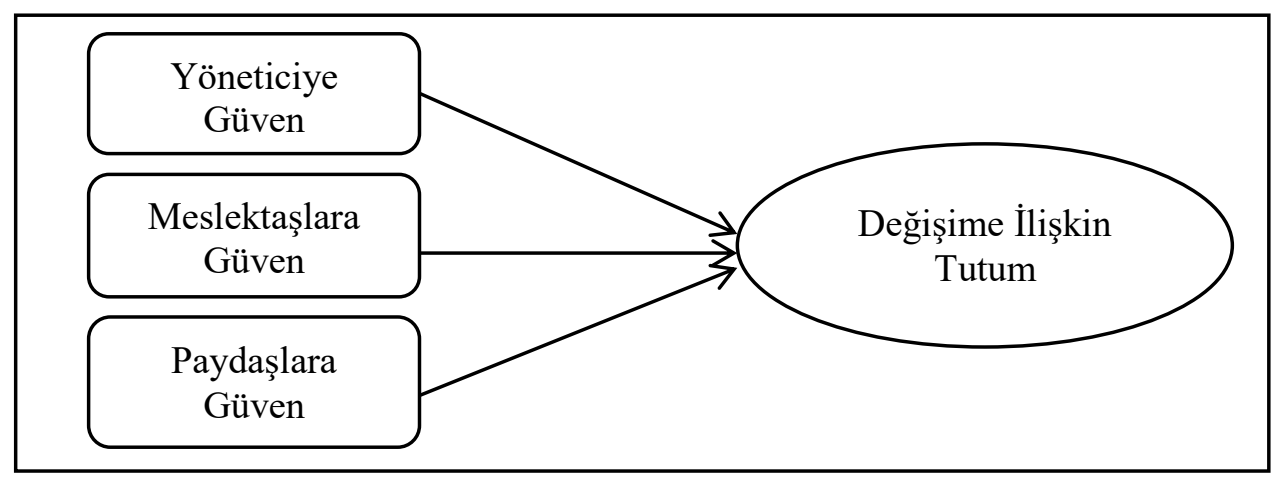

Şekil 1. Regresyon modeli

\section{BULGULAR}

\section{1. Öğretmenlerin Örgütsel Güven Algıları ve Değişime İlişkin Tutumlarının Düzeyleri}

Öğretmenlerin örgütsel güven düzeylerine ilişkin bulgular Tablo 2'de verilmiştir.

Tablo 2. Öğretmenlerin örgütsel güven düzeyleri

\begin{tabular}{llllll}
\hline & Min. & Max. & $\overline{\mathbf{x}}$ & Ss & Katılım Düzeyi \\
\hline Meslektaşlara Güven & 2.71 & 5.00 & 4.22 & .64 & Çok yüksek \\
Paydaşlara Güven & 1.50 & 5.00 & 3.26 & .58 & Orta \\
Yöneticiye Güven & 2.80 & 5.00 & 4.45 & .57 & Çok yüksek \\
Örgütsel Güven & 2.45 & 5.00 & 3.90 & .50 & Yüksek \\
\hline
\end{tabular}

Tablo 2 incelendiğinde, öğretmenlerin okullarında en çok yöneticiye $(\overline{\mathrm{x}}=4.45)$, en az öğrenci ve velilere $(\bar{x}=3.26)$ güvendikleri görülmektedir. Öğretmenlerin örgütsel güven algılarının yüksek düzeyde $(\overline{\mathrm{x}}=3.90)$ olduğu belirlenmiştir.

Öğretmenlerin değişime ilişkin tutum düzeylerine ait bulgular Tablo 3 'te verilmiştir.

Tablo 3. Öğretmenlerin değişime ilişkin tutum düzeyleri

\begin{tabular}{llllll}
\hline & Min. & Max. & $\overline{\mathbf{x}}$ & Ss & Katılım Düzeyi \\
\hline Bilişsel & 2.83 & 5.00 & 4.16 & .59 & Yüksek \\
Duyuşsal & 2.50 & 5.00 & 3.98 & .59 & Yüksek \\
Psikomotor & 2.17 & 5.00 & 3.83 & .67 & Yüksek \\
Örgütsel Değişim & 2.78 & 5.00 & 3.99 & .57 & Yüksek \\
\hline
\end{tabular}

Tablo 3 incelendiğinde öğretmenlerin en çok bilişsel boyuta $(\bar{x}=4.16)$, en az psikomotor boyuta $(\overline{\mathrm{x}}=3.83)$ ilişkin tutum sergiledikleri tespit edilmiştir. Ayrıca öğretmenlerin değişime ilişkin tutumlarının yüksek düzeyde ( $\bar{x}=3.99)$ olduğu belirlenmiştir.

\section{2. Öğretmenlerin Örgütsel Güven Algıları ve Değişime İlişkin Tutumlarının Bazı Demografik} Değişkenlerine Göre Karşılaştırılması

Öğretmenlerin cinsiyet, yaş, kıdem ve branş demografik değişkenlerine göre örgütsel güven algıları ve değişime ilişkin tutumlarına ait bulgular tablolar halinde sunulmuştur.

\subsection{1. Öğretmenlerin Örgütsel Güven Algıları ve Değişime İlişkin Tutumlarının Cinsiyet Değişkeni Açısından Değerlendirilmesine İlişkin Bulgular}

Öğretmenlerin cinsiyetlerine göre örgütsel güven algıları ve değişime ilişkin tutumları Tablo 4'te sunulmuştur. 
Tablo 4. Cinsiyete göre öğretmenlerin örgütsel güven algıları ve değişime ilişkin tutumları

\begin{tabular}{llllllll}
\hline Bağımıı Değişkenler & $\begin{array}{l}\text { Bağımsız } \\
\text { Değişken } \\
\text { (Cinsiyet) }\end{array}$ & $\mathbf{N}$ & $\overline{\mathbf{x}}$ & $\mathbf{s s}$ & $\mathbf{s d}$ & $\mathbf{t}$ & $\mathbf{p}$ \\
& Kadın & 160 & 3.86 & .51 & 313 & -1.144 & .253 \\
\hline Örgütsel Güven Algısı & Erkek & 155 & 3.92 & .49 & & & \\
& Kadın & 160 & 4.00 & .56 & 313 & .234 & .815 \\
& Erkek & 155 & 3.98 & .59 & & & \\
\hline
\end{tabular}

Tablo 4 incelendiğinde, öğretmenlerin cinsiyetine göre örgütsel güvene ilişkin algıları $(\mathrm{t}=.253$; $\mathrm{p}>.05)$ ve örgütsel değişime ilişkin tutumları $(\mathrm{t}=.815 ; \mathrm{p}>.05)$ arasında anlamlı fark olmadığ 1 belirlenmiştir.

\subsection{2. Öğretmenlerin Örgütsel Güven Algıları ve Değişime İlişkin Tutumlarının Yaş Değişkeni Açısından Değerlendirilmesine İlişskin Bulgular}

Öğretmenlerin yaşlarına göre örgütsel güven algıları ve değişime ilişkin tutumları Tablo 5 'te sunulmuştur.

Tablo 5. Öğretmenlerin örgütsel güven algıları ve örgütsel değişime ilişkin tutumlarının yaşa göre karşılaştırılması

\begin{tabular}{|c|c|c|c|c|c|c|c|c|c|}
\hline $\begin{array}{l}\text { Bağımlı } \\
\text { Değişkenler }\end{array}$ & $\begin{array}{l}\text { Bağımsız } \\
\text { Değişken (Yaş) }\end{array}$ & $\mathbf{N}$ & $\overline{\mathbf{x}}$ & SS & $\begin{array}{l}\text { sd } \\
\text { (Gruplar } \\
\text { Arası) }\end{array}$ & $\begin{array}{l}\text { sd } \\
\text { (Grup } \\
\text { İçi) }\end{array}$ & $\mathbf{F}$ & $\mathbf{p}$ & $\begin{array}{l}\text { Anlamlı } \\
\text { Fark }\end{array}$ \\
\hline Örgütsel & & & & & 2 & 312 & .526 & .592 & - \\
\hline Güven & $21-30$ yaş $(\mathrm{A})$ & 117 & 3.87 & .48 & & & & & \\
\hline \multirow[t]{2}{*}{ Algisı } & $31-40$ yaş (B) & 143 & 3.93 & .53 & & & & & \\
\hline & 41 yaş ve üzeri (C) & 55 & 3.87 & .48 & & & & & \\
\hline Değişime & & & & & 2 & 312 & 5.532 & .004 & A-C \\
\hline İlişkin & $21-30$ yaş $(\mathrm{A})$ & 117 & 4.00 & .56 & & & & & B-C \\
\hline \multirow[t]{2}{*}{ Tutum } & $31-40$ yaş (B) & 143 & 4.06 & .59 & & & & & \\
\hline & 41 yaş ve üzeri (C) & 55 & 3.77 & .51 & & & & & \\
\hline
\end{tabular}

Tablo 5 incelendiğinde, öğretmenlerin yaşlarına göre örgütsel güvene ilişkin algılarının anlamlı farklılık göstermediği ( $>>05)$, değişime ilişkin tutumlarının ise anlamlı farklılık gösterdiği tespit edilmiştir $\left(\mathrm{F}_{(2-312)}=5.532, \mathrm{p}<.01\right)$. Öğretmenlerin değişime ilişkin tutumlarının hangi alt gruplar arasında farklılaştığını belirlemek amacıyla yapılan Post-hoc Tukey testi sonucunda 41 yaş üzeri olan öğretmenler ile 21-30 yaş grubunda yer alan öğretmenler arasında $(\mathrm{I}-\mathrm{J}=.238, \mathrm{p}=.028)$ ve 41 yaş üzeri olan öğretmenler ile 31-40 yaş grubunda yer alan öğretmenler arasında $(I-J=.297, p=.003)$; anlaml farkl1lıklar bulunmuştur. 41 yaş ve üzeri olan öğretmenlerin değişime ilişkin tutumlarının $(\overline{\mathrm{x}}=3.76)$, 21-30 yaş öğretmenlerin tutumlarından $(\overline{\mathrm{x}}=4.00)$ ve $31-40$ yaş öğretmenlerin tutumlarından $(\overline{\mathrm{x}}=4.06)$ düşük olduğu belirlenmiştir. Bu çalışmada tek yönlü varyans analizleri sonucunda farkın anlamlı çıkması durumunda değişkenler arasındaki ilişkinin gücünü kararlaştırmada Eta- kare korelasyon katsayısı=Gruplar arası kareler toplamı/Toplam kareler toplamı formülü ile hesaplanmıştır (Büyüköztürk, 2017). Eta kare korelasyon katsayısı .10'dan az ise küçük etki, .25 yakın ise orta etki, .40'dan fazla ise büyük etkiyi ifade eder (Cohen, 1992). Öğretmenlerin değişime ilişkin tutumları yaş değişkenine göre farklılaştığı için etki büyüklüğü hesaplanmıştır. Hesaplanan eta-kare değerine $\left(\eta^{2}=.0342\right)$ göre öğretmenlerin yaş değişkeni, değişime ilişkin tutumları üzerinde "küçük" etki düzeyine sahiptir.

\subsection{3. Öğretmenlerin Örgütsel Güven Algıları ve Değişime İlişkin Tutumlarının Kıdem Değişkeni Açısından Değerlendirilmesine İlişkin Bulgular}

Öğretmenlerin kıdemlerine göre örgütsel güven algıları ve değişime ilişkin tutumları Tablo 6' da sunulmuştur. 
Tablo 6. Öğretmenlerin örgütsel güven algıları ve değişime ilişkin tutumlarının kıdemlerine göre karş1laştırılması

\begin{tabular}{|c|c|c|c|c|c|c|c|c|c|}
\hline $\begin{array}{l}\text { Bağımlı } \\
\text { Değişkenler }\end{array}$ & $\begin{array}{l}\text { Bağımsız } \\
\text { Değişken } \\
\text { (Kıdem) }\end{array}$ & $\mathbf{N}$ & $\overline{\mathbf{x}}$ & ss & $\begin{array}{l}\text { sd } \\
\text { (Gruplar } \\
\text { Arasi) }\end{array}$ & $\begin{array}{l}\text { sd } \\
\text { (Grup } \\
\text { İçi) }\end{array}$ & $\mathbf{F}$ & $\mathbf{p}$ & $\begin{array}{l}\text { Anlamlı } \\
\text { Fark }\end{array}$ \\
\hline Örgütsel & & & & & 2 & 312 & .449 & .639 & - \\
\hline Güven & $1-10 \mathrm{y} 1 \mathrm{l}(\mathrm{A})$ & 195 & 3.92 & .51 & & & & & \\
\hline \multirow[t]{2}{*}{ Algisi } & $11-20 \mathrm{yll}(\mathrm{B})$ & 75 & 3.86 & .49 & & & & & \\
\hline & 21 yıl ve üzeri (C) & 45 & 3.86 & .48 & & & & & \\
\hline Değişime & & & & & 2 & 312 & 5.606 & .004 & A-C \\
\hline İlişkin & $1-10 \mathrm{y} 1 \mathrm{l}(\mathrm{A})$ & 195 & 4.07 & .56 & & & & & \\
\hline \multirow[t]{2}{*}{ Tutum } & $11-20$ yıl (B) & 75 & 3.89 & .59 & & & & & \\
\hline & 21 yıl ve üzeri (C) & 45 & 3.80 & .53 & & & & & \\
\hline
\end{tabular}

Tablo 6'da görüldüğü gibi, öğretmenlerin kıdemlerine göre örgütsel güvene ilişkin algılarının anlamlı farklılık göstermediği ( $>$ >.05), değişime ilişkin tutumlarının ise anlamlı farklılık gösterdiği anlaşılmaktadır $\left(\mathrm{F}_{(2-312)}=5.606, \mathrm{p}<.01\right)$. Post-hoc Tukey testi sonucunda 21 yıl ve üzeri kıdeme sahip öğretmenler ile 1-10 y1l kıdeme sahip öğretmenlerin değişime ilişkin tutumları arasında (I-J= .269, p= .012) anlamlı farklılıklar bulunmuştur. 1-10 y1l kıdeme sahip öğretmenlerin değişime ilişkin tutumlarının $(\overline{\mathrm{x}}=4.07), 21$ yıl ve üzeri kıdeme sahip öğretmenlerin tutumlarından $(\overline{\mathrm{x}}=3.80)$ yüksek olduğu gözlenmiştir. Kıdem değişkeninin değişime ilişkin tutum üzerindeki etki düzeyini belirlemek için hesaplanan eta-kare değerine $\left(\eta^{2}=.0347\right)$ göre öğretmenlerin kıdem değişkeni, değişime ilişkin tutumları üzerinde "küçük" etki düzeyine sahiptir.

3.2.4. Öğretmenlerin Örgütsel Güven Algıları ve Değişime İlişkin Tutumlarının Branş Değişkeni Açısından Değerlendirilmesine İlişkin Bulgular

Öğretmenlerin branşlarına göre örgütsel güven algıları ve değişime ilişkin tutumları Tablo 7'de sunulmuştur.

Tablo 7. Öğretmenlerin örgütsel güven algıları ve değişime ilişkin tutumlarının branşlarına göre karşılaştırılması

\begin{tabular}{|c|c|c|c|c|c|c|c|c|c|}
\hline $\begin{array}{l}\text { Bağımlı } \\
\text { Değişkenler }\end{array}$ & $\begin{array}{l}\text { Bağımsız } \\
\text { Değişken } \\
\text { (Branş) }\end{array}$ & $\mathbf{N}$ & $\overline{\mathbf{x}}$ & SS & $\begin{array}{l}\text { sd } \\
\text { (Gruplar } \\
\text { Arasi) }\end{array}$ & $\begin{array}{l}\text { sd } \\
\text { (Grup } \\
\text { İçi) }\end{array}$ & $\mathbf{F}$ & p & $\begin{array}{l}\text { Anlamlı } \\
\text { Fark }\end{array}$ \\
\hline Örgütsel & & & & & 3 & 311 & .073 & .975 & - \\
\hline \multirow[t]{4}{*}{ Güven Algısı } & Sinıf & 74 & 3.90 & .48 & & & & & \\
\hline & Sayısal Dersler & 80 & 3.89 & .48 & & & & & \\
\hline & Sözel Dersler & 92 & 3.88 & .53 & & & & & \\
\hline & Diğer Dersler & 69 & 3.92 & .51 & & & & & \\
\hline Değişime & & & & & 3 & 311 & 1.958 & .120 & - \\
\hline \multirow[t]{4}{*}{ İlişkin Tutum } & Sinif & 74 & 3.98 & .56 & & & & & \\
\hline & Sayısal Dersler & 80 & 3.91 & .51 & & & & & \\
\hline & Sözel Dersler & 92 & 3.96 & .61 & & & & & \\
\hline & Diğer Dersler & 69 & 4.13 & .59 & & & & & \\
\hline
\end{tabular}

Tablo 7'de görüldüğg̈ gibi, öğretmenlerin branşlarına göre yapılan karşılaştırmalarda, grupların örgütsel güvene ilişkin algıları arasında $(\mathrm{F}=.073 ; \mathrm{p}>.05)$ ve değişime ilişkin tutumları arasında $(\mathrm{F}=$ $1.958 ; \mathrm{p}>.05)$ anlamlı fark olmadığ

\section{3. Öğretmenlerin Örgütsel Güven Algılarının Değişime İlişsin Tutumları Üzerinde Etkisi}

Araştırmada yordayan ve yordanan değişkenler arasındaki ilişkileri belirlemek için korelasyon analizi yapılmıştır. Değişkenler arasındaki korelasyon analizi sonuçları Tablo 8'de verilmiştir. 
Tablo 8. Değişkenlere ait korelasyon değerleri

\begin{tabular}{lllll}
\hline Değişken & $\mathbf{1}$ & $\mathbf{2}$ & $\mathbf{3}$ & $\mathbf{4}$ \\
\hline Meslektaşlara Güven (1) & 1 & & & \\
Paydaşlara Güven (2) & $.533^{* *}$ & 1 & & \\
Yöneticiye Güven (3) & $.675^{* *}$ & $.453^{* *}$ & 1 & \\
Değişime İlişkin Tutum (4) & $.419^{* *}$ & $.374^{* *}$ & $.437^{* *}$ & 1 \\
\hline ** Korelasyon .01 düzeyinde anlamlıdır. & & & &
\end{tabular}

** Korelasyon .01 düzeyinde anlamlıdır.

Tablo 8 incelendiğinde örgütsel güvenin meslektaşlara güven ile paydaşlara güven $(\mathrm{r}=.53, \mathrm{p}<$ $.01)$, meslektaşlara güven ile yöneticiye güven $(\mathrm{r}=.67, \mathrm{p}<.01)$ boyutları arasında orta düzeyde; paydaşlara güven ile yöneticiye güven $(\mathrm{r}=.45, \mathrm{p}<.01)$ boyutları arasında düşük düzeyde pozitif yönde anlamlı ilişki olduğu görülmektedir. Ayrıca değişime ilişkin tutum ile örgütsel güvenin meslektaşlara güven $(\mathrm{r}=.42, \mathrm{p}<.01)$, paydaşlara güven $(\mathrm{r}=.37, \mathrm{p}<.01)$ ve yöneticiye güven $(\mathrm{r}=.44, \mathrm{p}<.01)$ boyutları arasında düşük düzeyde pozitif yönde anlamlı ilişki olduğu tespit edilmiştir.

Öğretmenlerin örgütsel güven (meslektaşlara güven, paydaşlara güven ve yöneticiye güven) algılarının değişime ilişkin tutumlarını anlamlı bir şekilde yordayıp yordamadığını belirlemek amacıyla çoklu regresyon analizi yapılmıştır. Analiz sonuçları Tablo 9'da verilmiştir.

Tablo 9. Öğretmenlerin değişime ilişkin tutumları üzerinde örgütsel güvenin etkisi

\begin{tabular}{|c|c|c|c|c|c|c|c|c|c|c|}
\hline $\begin{array}{l}\text { Yordanan } \\
\text { Değişken }\end{array}$ & $\begin{array}{l}\text { Analiz } \\
\text { Aşaması }\end{array}$ & $\begin{array}{l}\text { Yordayan } \\
\text { Değişkenler }\end{array}$ & $\mathbf{B}$ & Std. & $\beta$ & $\mathbf{t}$ & $\mathbf{p}$ & $\mathbf{R}$ & $\mathbf{R}^{2}$ & $\Delta \mathbf{R 2}$ \\
\hline Değișime & 1 & Sabit & 2.04 & .23 & & 8.90 & .00 & .44 & .19 & .188 \\
\hline İlişkin & & Yöneticiye Güven & .44 & .05 & .44 & 8.59 & & & & \\
\hline \multirow[t]{7}{*}{ Tutum } & 2 & Sabit & 1.77 & .23 & & 7.57 & .00 & .48 & .23 & .225 \\
\hline & & Yöneticiye Güven & .34 & .06 & .34 & 6.03 & & & & \\
\hline & & Meslektaşlara Güven & .22 & .06 & .22 & 3.99 & & & & \\
\hline & 3 & Sabit & 1.70 & .24 & & 7.26 & .00 & .49 & .24 & .234 \\
\hline & & Yöneticiye Güven & .25 & .07 & .25 & 3.72 & & & & \\
\hline & & Meslektaşlara Güven & .18 & .06 & .18 & 3.02 & & & & \\
\hline & & Paydaşlara Güven & .14 & .06 & .16 & 2.17 & & & & \\
\hline
\end{tabular}

Tablo 9'da $\mathrm{R}^{2}$ değerleri incelendiğinde, ilk aşamada öğretmenlerin yöneticiye güven algılarının toplam varyansın \% 19'unu açıkladığı görülmektedir $(\mathrm{F}=73.68 ; \mathrm{p}<.01)$. İkinci aşamada meslektaşlara güven değişkeni ile birlikte toplam varyans \% 23'e $(\mathrm{F}=46.45 ; \mathrm{p}<.01)$; üçüncü aşamada paydaşlara güven puanlarının yordamaya katılması ile \% 24'e $(\mathrm{F}=32.96 ; \mathrm{p}<.01)$ yükselmiş̧ir. Çoklu regresyon analizi sonucunda en önemli yordama katkısının yöneticiye güven algısından geldiği, bunu sırasıyla meslektaşlara güven algısı ve paydaşlara güven algısının izlediği saptanmıştır. Öğretmenlerin yöneticiye güven algılarında bir birim artma olduğunda değişime ilişkin tutumlarının .44, meslektaşlara güven algılarında bir birim artma olduğunda değişime ilişkin tutumlarının .22 ve paydaşlara güven algılarında bir birim artma olduğunda ise değişime ilişkin tutumlarının .14 birim artacağı belirlenmiştir.

\section{TARTIŞMA ve SONUÇ}

$\mathrm{Bu}$ araştırmada, öğretmenlerin örgütsel güven algıları ve değişime ilişkin tutumlarının düzeylerini saptamak ve örgütsel güvenin alt boyutları yöneticiye güven, meslektaşlara güven ve paydaşlara güvenin değişime ilişkin tutum üzerindeki etkisini belirlemek amaçlanmıştır.

Araştırmada öğretmenlerin okullarında en çok yöneticilerine, ikinci sırada meslektaşlarına, son olarak öğrenci ve velilere güvendikleri sonucuna ulaşılmıştır. Öğretmenlerin yöneticilerine güven duyması, okulların işleyişi açısından çok önemlidir. Çünkü yöneticilerine güvenen öğretmenler daha işbirlikçi, fedakar ve yeniliğe açık davranışlar gösterebilmektedir. Okullarda güven ortamını oluşturmada okul müdürünün rolü kritik öneme sahiptir. Çoğu kez, güven ve karşıllklı saygı atmosferi, okul müdürlerinin mizaçlarına ve özgün kişiliğine atfedilir (Reeves, Emerick \& Hirsch, 2007). Öğretmenlerin aynı işi yaptıkları, aynı sorunlarla karşılaştıkları meslektaşlarına daha fazla güven duyması gerekirken yöneticilerine daha çok güven duymalarının sebebi, öğretmenler arası rekabet (Yılmaz, 2009) ya da öğretmenlerin herhangi bir problemle karşılaştıklarında en çok yöneticilerden yardım alması gösterilebilir. Cook ve Wall (1980) örgütlerin uzun sürede istikrarlı 
olmaları için, örgütte çalışanlar arasındaki güvenin çok önemli bir faktör olduğunu belirtmişlerdir. Ayrıca Schaubroeck, Peng ve Hannah (2013) tarafından gerçekleştirilen araştırmada, çalışma arkadaşlarına olan güvenin örgütsel kimliği pozitif yönde etkilediği belirlenmiştir. Eğitim-öğretim sürecinde öğrencileri hayata hazırlayan öğretmenlerin, öğrenciler ve veliler ile işbirliği yapması eğitimin kalitesini artırmasına rağmen öğretmenler en az öğrenci ve velilere güvenmektedirler. Benzer şekilde Ayık, Savaş ve Çelikel (2014), Bökeoğlu ve Yılmaz (2008), Ergün (2017), Tschannen-Moran (2001) çalışmalarında öğretmenlerin en çok yöneticilerine, en az paydaşlarına güvendikleri sonucuna ulaşmışlardır. Yılmaz (2009) ise çalışmasında öğretmenlerin en çok yöneticilerine, en az meslektaşlarına güven duydukları bulgusuna ulaşmıştır. Öğretmenlerin örgütsel güven ölçeğinin tamamına ilişkin algıları yüksek düzeyde toplanmıştır. Bu sonuç öğretmenlerin okullarda güven algısına sahip olduklarını göstermektedir. Öğretmenlerin çalıştığı kurumda yüksek düzeyde güven algısına sahip olmaları eğitim-öğretim faaliyetlerinin amaçlarına etkili şekilde ulaşmasına katkıda bulunur. Çünkü çalışanların kurumlarına duygusal açıdan bağlanmalarının (Eren, 2014; Top, 2012), yaptıkları işten tatmin olmalarının (Guinot, Chiva \& Puig, 2014; İşcan \& Sayın, 2010; Straiter, 2005; Top 2010), kurumun amaçları ile özdeşleşmelerinin (Tokgöz \& Seymen, 2013) ve değişime açık olmalarının (Davis, Schoorman, Mayer \& Tan, 2000) temelinde güvene dayalı ilişkilerin kurulması yatar. Örgütsel güven, iş stresi (Guinot, Chiva \& Puig, 2014) ve üretkenlik karşıtı davranışlara (Colquit, Scott \& LePine, 2007) negatif yönde etki ederek örgütsel performans (Colquit, Scott \& LePine, 2007; Guinot, Chiva \& Mallen, 2013; Jones \& George, 1998) ve iş grubuna uyum (Gilbert \& Tang, 1998) sağlar. Ayrıca Meng (2015) örgütlerde karş1lıklı güvenin artmasının denetim ve gözetim faaliyetlerinin azalmasında önemli bir rol oynadığını belirtmiştir. Bu çalışma ile benzer şekilde Polat ve Celep (2008) ise çalışmalarında öğretmenlerin yüksek düzeyde güvene sahip oldukları sonucuna ulaşmışlardır. Alanyazında öğretmenlerin orta düzeyde güvene sahip olduklarını belirleyen araştırmalara da rastlanmaktadır (Bökeoğlu \& Yılmaz, 2008; Kalaycı, 2007; Yıldız, 2013).

Öğretmenlerin değişim ve alt boyutlarına ilişkin tutumlarının sonuçları incelendiğinde en yüksek ortalama puanın bilişsel boyuta, ikinci sırada duyuşsal boyuta ve en düşük ortalama puanın psikomotor boyuta ait olduğu görülmektedir. Bu sonuç tutumun psikomotor yani davranışşal öğesinin bilişsel ve duyuşsal öğelerinin sonucunda ortaya çıtığını gösterebilir (İnceoğlu, 2010). Bu çalışmadan farklı olarak Tanrı̈̆ğen (2000), öğretmenlerin en çok psikomotor boyuta ilişkin olumlu tutum geliştirdiklerini saptamıştır. Öğretmenlerin değişme tutum ölçeğinin tamamına ilişkin tutumları yüksek düzeydedir. Tüm örgütler gibi okullar da değişim gereksinmelerinden etkilenmektedir. Özellikle okullar, açık bir sistem olduğu için değişime karşı daha kırılgan bir yapıya sahiptirler. Bu nedenle, okullarda değişim son derece doğal ve kaçınılmaz bir olgudur (Beycioğlu \& Aslan, 2010). Öğretmenlerin okullarda yaşanacak değişim girişimlerine karşı olumlu tutum geliştirmesi, değişim sürecinde ihtiyaç olan insan gücünün sağlanması açısından kritik bir öneme sahiptir. Diğer bir ifadeyle öğretmenlerin değişim faaliyetlerini desteklemeleri, bu faaliyetlerin başarıya ulaşması için gerekli ilk adımdır. Bu çalışmadan farklı olarak Kurşunoğlu ve Tanrıöğen (2006) çalışmalarında öğretmenlerin örgütsel değişime ilişkin tutumlarının orta düzeyde toplandığ 1 sonucuna ulaşmışlardır.

Çalışmada öğretmenlerin cinsiyetlerine, yaşlarına, kıdemlerine ve branşlarına göre örgütsel güvene ilişkin algıları arasında anlamlı farklılık olmadığı belirlenmiştir. Bu sonuca göre alınan değişkenlerin öğretmenlerin örgütsel güven algılarını etkilemediği söylenebilir. Öğretmenlerin aynı kurumun olanaklarından yararlanmaları, aynı ortamı paylaşmaları ve benzer eğitimlerden geçmeleri örgütsel güvene ilişkin algılarının benzer olmasını açıklayabilir. Çalışmayı destekler şekilde öğretmenlerin örgütsel güven algıları ile ilgili olarak Memduhoğlu ve Zengin (2011) cinsiyet, branş ve kıdemleri; Ercan (2006) branşları arasında anlamlı farklılık olmadığ 1 sonucuna ulaşmışlardır. Ancak Çağlar (2011), Ercan (2006), Semercioğlu, Tengilimoğlu ve Semercioğlu (2012) ile Özer, Demirtaş, Üstüner ve Cömert'in (2006) çalışmalarında ise, örgütsel güvene ilişkin erkek öğretmenlerin algılarının kadın öğretmenlerin algılarına göre daha yüksek olduğu sonucuna varılmıştır. Yine bu çalışmanın sonucundan farklı olarak çalışanların örgütsel güven algıları ile kıdemleri arasındaki ilişkinin incelendiği Çağlar (2011), Gilbert ve Tang (1998) ve Özer ve diğerlerinin (2006) çalışmalarında çalışanların kıdemleri arttıkça güven düzeyinin de artmakta olduğu sonucuna ulaşılmıştır. Ayrıca Çağlar (2011), sınıf öğretmenlerinin güven düzeyinin sosyal bilimler ve fen bilimleri alanındaki öğretmenlere oranla daha yüksek olduğu sonucuna ulaşmıştır. 
Çalışmada öğretmenlerin cinsiyetlerine ve branşlarına göre değişime ilişkin tutumları arasında anlamlı farklılık olmadığı belirlenmiştir. Sonuçlara göre, cinsiyet ve branş değişkenlerinin öğretmenlerin değişime ilişkin tutumlarını etkilemediği ileri sürülebilir. Alan yazında bu araştırma sonuçlarına paralel olarak öğretmenlerin cinsiyet ve branş değişkenleriyle Tanrıöğen (2000) ve Taşdan (2013), cinsiyet değişkeniyle Kurşunoğlu ve Tanrı̈ğen (2006) ile Aydoğan (2007) değişime ilişkin tutumları arasında anlamlı bir farklılık olmadığ 1 sonucuna ulaşmışlardır. Öğretmenlerin değişime ilişkin tutumlarının yaşlarına ve kıdemlerine göre farklılaştığı sonucuna ulaşılmıştır. 41 yaş ve üzeri olan öğretmenlerin değişime ilişkin tutumlarının, 21-30 yaş ile 31-40 yaş grubundaki öğretmenlerin tutumlarından düşük olduğu saptanmıştır. 41 ve üzeri yaştaki öğretmenlerin değişime ilişkin tutumlarının düşük çıkmasının nedeni uzun süre yaşadıkları alışkanlıkları ve davranışlarını değiştirmek istemediklerinden kaynaklanabilir. Yine yaş değişkeni ile uyumlu olarak çalışmada 1-9 yıl kıdeme sahip öğretmenlerin değişime ilişkin tutumlarının, 10-19 yıl ile 21 yıl ve üzeri kıdeme sahip öğretmenlerin tutumlarından yüksek olduğu bulunmuştur. Bu sonuçlar 1şı̆̆ında daha az kıdeme sahip öğretmenlerin daha dinamik ve hevesli olabilecekleri, uzun yıllar mesleğin içinde olan öğretmenlerin ise motivasyon düzeylerinin düşmüş olabileceği bu nedenle de değişime ilişkin tutumlarında azalma olacağı söylenebilir. Bu çalışmayla uyumlu olarak Taşdan (2013) mesleki kıdemi az olan öğretmenlerin değişime karşı daha olumlu tutum geliştirdikleri sonucuna ulaşmıştır. Van Wagoner (2004) da çalışanların bir kurumda görev süreleri arttıkça, değişmeyi daha az benimsedikleri sonucuna ulaşmıştır. Buna karşın Kurşunoğlu ve Tanrıöğen (2006) kıdemin öğretmenlerin örgütsel değişimi algılamaları üzerinde etkili olmadığı sonucuna varmışlardır.

Öğretmenlerin örgütsel güvenin tüm boyutlarına (meslektaşlara, öğrenci ve velilere, yöneticilere güven) ilişkin algıları ile değişime ilişkin tutumları arasında anlamlı ve pozitif bir ilişki olduğu sonucuna ulaşılmıştır. Buna göre güçlü bir örgütsel güven ortamı oluşturmanın, örgütsel öğrenme Guinot, Chiva ve Mallen, 2013) ve risk alma davranışlarını (Colquit, Scott \& LePine, 2007) olumlu yönde etkileyerek değişim girişimlerinin başarıyla gerçekleştirilmesi açısından önemli olduğu söylenebilir. Alan yazında örgütlerdeki değişim girişimlerinin başarıyla sonuçlanmasında önemli rol oynayan örgütsel adalet (Hoy \& Tarter, 2004; Şevik, 2012), örgütsel bağlllık (Baek \& Jung, 2014; Çubukçu \& Tarakçıŏlu, 2010; Demirel 2008; Straiter, 2005; Wang, Tsai \& Lin, 2013), işbirliği yapma (Cerit, 2009), iş doyumu (Semercioğlu, Tengilimoğlu \& Semercioğlu, 2012), eşitlik (Maele, Forsyth \& Houtte, 2014), örgütsel vatandaşlık (Tokgöz \& Seymen, 2013; Wang, Tsai \& Lin, 2013; Yücel \& Samanc1, 2009), karara katılma ve takım çalışması (Shagholi, Hussin, Siraj, Naimie, Assadzadeh \& Moayedi, 2010) gibi kavramlar ile örgütsel güven arasında anlamlı pozitif ilişkiler bulunmuştur. Örgütlerdeki güven ortamının sonucu olan duygusal zeka (Vakola, Tsaousis \& Nikolaou, 2004), iletişim (Elving, 2005), sosyal ilişkiler ve örgütsel bağl1lık (Madsen, Miller \& John, 2005) ile örgütsel değişim arasında pozitif anlamlı ilişkiler olduğu sonucuna ulaşılmıştır. Araştırmada; yöneticilere, meslektaşlara, öğrenci ve velilere güvenin öğretmenlerin değişime ilişkin tutumlarının anlamlı yordayıcıları olduğu belirlenmiştir. Çalışma hayatının en önemli unsurlarından olan örgütsel güven, çalışanların örgüte duygusal açıdan bağlanmalarını, işlerinden tatmin olmalarını (Demircan \& Ceylan, 2003), işbirliği yapmalarını ve yeniliklere açık olmalarını sağlayan bir faktördür. Örgüt içi ilişkilerin anahtar öğesi olan güven olgusunun (Krotand \& Lewicka, 2012) hâkim olduğu okullarda öğretmenler, daha rahat ve özverili çalışacaklarından kendilerini ve kurumlarını geliştirmek için değişime daha açık hale gelebilirler. Sonuç olarak, öğretmenlerin değişime ilişkin olumlu tutum geliştirmeleri ve değişim girişimlerinin istenen sonuçlara ulaşması için güvene dayalı bir okul kültürü varlığının katalizör rol üstlendiği söylenebilir.

\section{1. Öneriler}

Öğretmenlerin örgütsel güven algıları ve değişime ilişkin tutumları arasındaki ilişkiyi inceleyen bu çalı̧̧ma, çalışma grubuyla ve kullanılan ölçeklerle sınırlıdır. $\mathrm{Bu}$ nedenle yapılacak olan çalışmaların daha büyük örneklem grubuna veya yükseköğretim kurumlarına uygulanması önerilebilir. Yeni çalışmalar, daha derinlemesine veriler elde etmek için nitel veri toplama teknikleri ile gerçekleştirilebilir. Ayrıca öğretmenlerin örgütsel güven algıları ve değişime ilişkin tutumları üzerinde etki göstermesi muhtemel başka parametrelerle de çalışmalar yapılabilir.

Öğretmenlerin paydaşlara duydukları güven düzeylerinin artması için okul-aile işbirliğinin öneminin kavranması ve etkin bir şekilde hayata geçirilmesi sağlanabilir. Öğrenci velilerinin okuldaki karar sürecine katılmaları ve okulu sık sık ziyaret etmeleri teşvik edilebilir. Yaşı ve kıdemi fazla olan 
öğretmenlerin değişime yönelik tutum düzeylerinin düşük olduğu sonucundan yola çıkarak, bu öğretmenlerin değişime ilişkin olumlu tutum geliştirmelerini sağlamak amaciyla değişim girişimlerinin iyi anlatılması ve belirsizliklerin en aza indirilmesi sağlanabilir. Değişimin kendilerine zarar değil, katkı sağlayacağı ve mesleki gelişimlerine olumlu yönde etki edeceği konusunda farkındalık yaratılabilir. Ayrıca değişime ilişkin olumlu tutum geliştirmeleri için yaşı ve kıdemi fazla olan öğretmenlere değişimin planlanması aşamasında görevler verilebilir. 


\section{KAYNAKLAR}

Aksoy, C. (2016). Çalışanların adalet algıları ve örgütsel güven düzeyleri arasındaki ilişkinin bankacılık sektörü açısından araştırılması. International Journal of Innovative Strategical Social Research, 1(2), 43-51.

AL-Abrrow HA, Shaker Ardakani M, Harooni A. (2013). The relationship between organizational trust and organizational justice components and their role in job involvement in education. International Journal of Management Academy, 1(1), 25-41.

Alwheeb, M. \& David, M. R. (2017). Assessing organizational readiness for the improvement and change initiatives in public hospitals. Management Issues in Healthcare System, 3, 49-57.

Aydoğan, İ. (2007). Değişim süreci ve okul personeli. GAU Journal of Social and Science. 3(5), 13-24.

Ayık, A., Savaş, M. \& Çelikel, G. (2014). Ortaöğretim kurumlarında görev yapan öğretmenlerin okul iklimi ve örgütsel güven algıları arasındaki ilişkinin incelenmesi. Mustafa Kemal Üniversitesi Sosyal Bilimler Enstitüsü Dergisi, 11 (27), 203-220.

Baek, Y. M. \& Jung, C. S. (2014). Focusing the mediating role of institutional trust: How does interpersonal trust promote organizational commitment? The Social Science Journal, In press, http://dx.doi.org/10.1016/j.soscij.2014.10.005.

Beycioğlu, K. \& Aslan, M. (2010).Okul gelişiminde temel dinamik olarak değişim ve yenileşme: Okul yöneticileri ve öğretmenlerin rolleri. Yüzüncü Yll Üniversitesi Eğitim Fakültesi Dergisi, 6(2), 153-173.

Bidarian, S., \& Jafari, P. (2012). The relationship between organizational justice and trust. Social and Behavioral Sciences, 47, 1622-1626.

Boonstra, J. (2004). Dynamics of organizational change and learning. Southerngate Chichester, West Sussex: John Wiley \& Sons Ltd.

Bökeoğlu, Ö. Ç. \& Yılmaz, K. (2008). İlköğretim okullarında örgütsel güven hakkında öğretmen görüşleri. Kuram ve Uygulamada Ĕgitim Yönetimi, 54, 211-233.

Bromiley, P. \& Cummings L. L. (1996). The organizational trust inventory (OTI). Roderick M. Kramer \& Tom R. Tyler (Eds.). Trust in organizations: 302-319. Thousand Oaks: Sage.

Büte, M. (2011). Etik iklim, örgütsel güven ve bireysel performans arasındaki ilişki. Atatürk Üniversitesi Iktisadi ve İdari Bilimler Dergisi, 25(1),171-192.

Büyüköztürk, Ş. (2017). Sosyal bilimler için veri analizi el kitabı: İstatistik, araştırma deseni, SPSS Uygulamaları ve yorum. (23. Bask1). Ankara: Pegem Akademi.

Candan, H. (2014). Çalışanların örgütsel adalet ve örgütsel güven algılamalarının örgütsel bağlılığa etkisi: Bir kamu kurumu üzerinde araştırma. Gaziantep University Journal of Social Sciences, 13(4), 889-917.

Cerit, Y. (2009). Öğretmenlerin örgütsel güven düzeyleri ile işbirliği yapma düzeyleri arasındaki ilişki. Uludağ Üniversitesi Ĕ̌itim Fakültesi Dergisi, 22(2), 637-657.

Cohen, J. (1992). A Power Primer. Psychological Bulletin, 112( I), 155-159.

Colquit, J. A., Scott, B. A. \& JePine, J. A. (2007), Trust, trustworthiness, and trust propensity: A Meta analytic test of their unique relations with risk taking and job performance, Journal of Applied Psychology, 92(4), 909927.

Cook, J. \& Wall, T. (1980). New work attitude measures of trust, organizational commitment and personal need non-fulfilment. Journal of Occupational Psychology, (53), 39-52.

Çağlar, Ç. (2011). Okullardaki örgütsel güven düzeyi ile öğretmenlerin mesleki tükenmişlik düzeyinin bazı değişkenler açısından incelenmesi. Kuram ve Uygulamada Ĕgitim Bilimleri, 11(4), 1827-1828.

Çelik, K. \& Tabancalı, E. (2012). Özel eğitim kurumlarında çalışan öğretmenlerin iş/çalışma yaşam kalitesi. Akdeniz Ĕ̈itim Araştırmaları Dergisi, 11, 31-38.

Çiçek, H. \& Şahin Macit, N. (2016). Konaklama işletmelerinde çalışanların örgütsel güveni ile iş tatmini arasındaki ilişkinin incelenmesi. Mehmet Akif Ersoy Üniversitesi Sosyal Bilimler Enstitüsü Dergisi, $8(14), 25-41$.

Çubukçu, K. \& Tarakçığlu, S. (2010). Örgütsel güven ve bağlılık ilişkisinin otelcilik ve turizm meslek lisesi öğretmenleri üzerinde incelenmesi. İşletme Araştırmaları Dergisi, 2 (4), 57-78.

Davis, J. H.,Schoorman, F. D., Mayer, R.C. \& Tan, H.H. (2000). The trusted general manager and business unit performance: empirical evidence of a competitive advantage. Strategic Management Journal, 21, 563576.

Das, T.K. \& Teng, B. (2001). Trust, control, and risk in strategic alliances: An integrated framework, Organization Studies, 22 (2), 251-283.

Demircan, N. \& Ceylan, A. (2003). Örgütsel güven kavramı: Nedenleri ve sonuçları. Yönetim ve Ekonomi. $10(2), 139-150$.

Demirel, Y. (2008). Örgütsel güvenin örgütsel bağlılık üzerine etkisi: tekstil sektörü çalışanlarına yönelik bir araştırma. Yönetim ve Ekonomi, 15(2), 179-194.

Ellis, K. \& Shockley-Zalabak, P. (2001). Trust in Top Management and Immediate Supervisor: The Relationship to Satisfaction, Perceived Organizational Effectiveness and Information Receiving. Communication Quarterly, 49(4), 382-398.

Elving, W. J. L. (2005). The role of communication in organisational change. Corporate Communications: An International Journal, 10( 2), 129 - 138. 
Ercan, Y. (2006). Okullardaki örgütsel güven düzeyinin bazı değişkenler açısından incelenmesi. Selçuk Üniversitesi Sosyal Bilimler Enstitüsü Dergisi, 16, 739-756.

Eren, M. Ş. (2014). Güçlendirme ve nicel işletme performansı arasındaki ilişkide örgüte güven ve duygusal bağlılı̆̆ın aracı etkileri. Işletme Araştırmaları Dergisi, 6(1), 303-327.

Ergün, H. (2017). Örgütsel muhalefete etki eden başlatıcı ve aracı değişkenler. Yayımlanmamış Doktora Tezi, Pamukkale Üniversitesi, Denizli.

Ferres, N.,Connell, J. \& Travaglione, A. (2004). Co-worker trust as a social catalyst for constructive employee attitudes, Journal of Managerial Psychology, 19(6), 608 - 622.

Finch, A. E. (2002) The language clinic: The teacher as an agent of change. ThaiTESOL Bulletin, August 2002, Special Issue, 35 - 52.

Fisher, R. (2012). Organizational justice research: Present perspectives and challenges. Revista Psicologia: Revista Psicologia: Organizações e Trabalho, 12(1), 97-112.

Genç, N. (2004). Yönetim ve organizasyon çağdaş sistemler ve yaklaşımlar. Ankara: Seçkin Yayıncılık.

George, M. P., White, G. P. \& Schlaffer, J. J. (2007). Implementing school-wide behavior change: Lessons from the field. Psychology in the Schools, 44(1), 41-51.

Gilbert, J. A. \& Tang, T. L. (1998). An examination of organizational trust antecedents. Public Personnel Management, 27(3), 321-338.

Gibson, J. G.,Ivancevich, J. M. \&Donnelly, J. H. (1988). Organizations. (Six Edition). Illinois: Business Publications.

Goddard, R. D.,Tschannen-Moran, M. \& Hoy, W. K. (2001). A multi level examination of the distribution and effects of teacher trust in students and parents in urban elementary schools. Elementary School Journal, 102(1), 3-17.

Goddard, R. G. \& Salloum, S.J. (2009). Trust as a mediator of the relationships between poverty, racial composition, and academic achievement evidence from michigan's public elementary schools. Educational Administration Quarterly, 45(2), 292-311.

Guinot, J., Chiva, R. \& Mallen, F. (2013). Organizational Trust and performance: Is organizational learning capability a missing link?. Journal of Management and Organization, 19(5), 559-582.

Guinot, J., Chiva, R. \& Puig, V. R. (2014). Interpersonal trust, stress and satisfaction at work: An empirical study. Personnel Review, 43(1), 96-115.

Halis, M., Gökgöz, S. G. \& Yaşar, Ö. (2007). Örgütsel güvenin belirleyici faktörleri ve bankacılık sektöründe bir uygulama. Sosyal Bilimler Dergisi, 17, 187-205.

Hanson, E.M. (1996). Educational administration and organizational behavior. (4th ed.). Boston: Allyn and Bacon.

Hooper, D., Coughlan J. \& Mullen, M. (2008). Structural equation modelling: guidelines for determining model fit. Electronic Journal of Business Research Methods, 6(1), 53-60.

Hoy, W. K. \& Tschannen-Moran, M. (2003). The conceptualization and measurement of faculty trust in schools. Wayne K. Hoy \& Cecil Miskel (Ed.). Studies in leading and organizing schools (pp. 181-207).

Hoy, W. K. \& DiPaola, M. F. (Eds.). (2008). Improving schools: Studies in leadership and culture. Charlotte, NC: Information Age Publishing.

Hoy, W. K. \&Tarter, C. J. (2004). Organizational justice in schools: no justice without trust. International Journal of Educational Management, 18(4), 250-259.

Hu, L. \& Bentler, P. M. (1999). Cutoff criteria for fit indexes in covariance structure analysis: Conventional criteria versus new alternatives, Structural Equation Modeling: A Multidisciplinary Journal, 6(1), 1-55.

Huck, S. W. (2008). Reading Statistics and Research, Boston, Pearson, (Electronic version, https://pendbingikgs.files.wordpress.com/2016/12/reading-statistics-and-research-sixth-edition.pdf).

Iqbal, Q. \& Ahmad, B. (2016). Organizational justice, trust, and organizational commitment in banking sector of Pakistan. Journal of Applied Economics and Business. 4(1), 26-43.

İlğan, A. (2007). Örgütsel değişim. Milli Ĕ̌itim Dergisi, 36(177), 80-103.

İnceoğlu, M. (2010). Tutum - algl-iletişim. (5. Basım). İstanbul: Beykent Üniversitesi Yayınevi.

İşcan, Ö. F. \& Sayın, U. (2010). Örgütsel adalet, iş tatmini ve örgütsel güven arasındaki ilişki. Atatürk Üniversitesi İ̈BF Dergisi, 24 (4), 195-216.

Jiang, Z., Gollan, P. J. ve Brooks, G. (2017). Relationships between organizational justice, organizational trust and organizational commitment: a cross-cultural study of China South Korea and Australia. The International Journal of Human Resource Management, 28 (7), 973-1004.

Jones, G. R. \& George, J. M. (1998). The Experience and evolution of trust: Implications for cooperation and teamwork, The Academy of Management Review, 23(3), 531-546.

Kalaycı, S. (2009). SPSS uygulamalı çok değiskenli istatistik teknikleri. Ankara: Asil Yayın Dağıtım.

Krot K. \& Lewicka, D. (2012). The importance of trust in manager-employee relationships. International Journal of Electronic Business Management, 10(3), 224-233.

Kurşunoğlu, A. \& Tanrıöğen, A. (2006). İlköğretim okulu öğretmenlerinin örgütsel değişmeye ilişkin tutumları. Pamukkale Üniversitesi Eğitim Fakültesi Dergisi, 20(2), 21-33. 
Lashari, M., Moazzam, A., Salman, Y. \& Irfan, S. (2016). Impact of organizational trust on organizational justice and organizational commitment: A case of university of Sargodha. JRSP, 53(2), 170-194.

Louis, K. S. (2007). Trust and improvement in schools. Journal of Educational Change ,8(1), 1-24.

Madsen, S. R., Miller, D. \& John, C. R. (2005). Readiness for organizational change: do organizational Commitment and social relationships in the work place make a difference?.Human Resource Development Quarterly, 16(2), 213-234.

Maele, D. V., Forsyth, P. B. \& Houtte, M. V. (2014). Trust and school life: The role of trust for learning, teaching, leading, and bridging. Dordrecht: Springer Science Business Media.

Memduhoğlu, H. B. \& Zengin, M. (2011). İlköğretim okullarında örgütsel güvene ilişkin öğretmen görüşleri. YYÜ Eğitim Fakültesi Dergisi, 8(1), 211-217.

Meng, X. (2015). The role of trust in relationship development and performance improvement. Journal of Civil Engineering and Management, 21(7), 845-853.

Mishra, A. (1996). Organizational response to crisis: The centrality of trust. in R. M. Kramer \& T. R. Tyler (Eds.). Trust in Organizations: Frontiers of Theory and Research, 261- 287.

Moore, D. M. (2010). Student and faculty perceptions of trust and their relationships to school success measures in an urban school district. Unpublished doctoral dissertation, Virginia: The College of William and Mary.

Nedkovski, V., Guerci, M., Battisti, F. \& Siletti, E. (2017). Organizational ethical climates and employee's trust in colleagues, the supervisor, and the organization. Journal of Business Research, 71, 19-26.

Neiva, E. R., Ros, M., \& Paz, M. G. T. (2005). Attitudes towards organizational change: Validation of a scale. Psychology in Spain, 2005, 9(1), 81-90.

Özer, N., Demirtaş, H., Üstüner, M. \& Cömert, M. (2006). Ortaöğretim öğretmenlerinin örgütsel güven algıları. Ege Eğitim Dergisi, 7(1), 103-124.

Paliszkiewicz, J. \& Koohang, A. (2013). Organizational trust as a foundation for knowledge sharing and its influence on organizational performance, Online Journal of Applied Knowledge Management, 1 (2), 116-127.

Polat, S. \& Celep, C. (2008). Ortaöğretim öğretmenlerinin örgütsel adalet, örgütsel güven, örgütsel vatandaşlık davranışlarına ilişkin algıları. Kuram ve Uygulamada Ĕgitim Yönetimi, 54, 307-331.

Reeves, C., Emerick, S. \& Hirsch, E. (2007). Creating an atmosphere of trust: lessons from exemplary schools. Hillsborough, NC: Center for Teaching Quality; North Carolina, Professional Teaching Standards Commission.

Rubagiza, J., Umutoni, J. \& Kaleeba, A. (2016). Teachers as agents of change: Promoting peacebuilding and social cohesion in schools in Rwanda. Education as Change, 20(3), 202-224.

Schaubroeck, J. M., Peng, A. C. \& Hannah, S. T. (2013). Developing trust with peers and leaders: Impacts on organizational identification and performance during entry, Academy of Management Journal, 56(4), 1148-1168.

Schermelleh-Engel, K., Moosbrugger, H., \& Müller, H. (2003). Evaluating the fit of structural equation models: Test of significance and descriptive goodness-of-fit measures. Methods of Psychological Research, 8(2), 23-74.

Semercioğlu, M. S.,Tengilimoğlu, D. \& Semercioğlu, M. G. (2012). Özel ve kamu personelinin iş doyumu ve örgütsel güven düzeylerinin karşılaştırılması, Sağlık Bilimleri Dergisi, 1(4), 225-238.

Shagholi, R., Hussin, S., Siraj, S., Naimie, Z., Assadzadeh, F. \& Moayedi F. (2010), Value creation through trust, decision making and teamwork in educational environment. Procedia-Socialand Behavioral Sciences, 2(2), 255-259.

Shockley-Zalabak, P.,Ellis, K. \& Winograd, G. (2000). Organizational trust: What it means, why it matters. Organization Development Journal, 18(4), 35-48.

Siddiqi, N. \& Kharshiing, K. D. (2015). Influence of organizational trust on job satisfaction and organizational commitment. Abhigyan, 33(2), 53-64.

Straiter, K. L. (2005). The effects of supervisors ${ }^{\text {ee }}$ Trust of subordinates and their organization on job satisfaction and organizational commitment. International Journal of Leadership Studies, 1(1), 86-101.

Tanrı̈ğen, A. (2000). Temel eğitim öğretmenlerinin değişmeye ilişkin tutumları. PAÜ Eğitim Fakültesi Dergisi, 7, 68-72.

Tanrı̈ğen, Z. M., Baştürk, R. \& Başer, Z. M. (2014). İlköğretim okullarında cinsiyet ve örgütsel rollere göre örgüt kültürü algısı. Trakya Üniversitesi Eğitim Fakültesi Dergisi, 4(1), 170-180.

Tan, H. H. \& Lim, A. K. (2009) Trust in coworkers and trust in organizations. The Journal of Psychology, $143(1), 45-66$.

Taşdan, M. (2013). İlköğretim okulu öğretmenleri için kişisel ve mesleki değişime açıklık ölçeklerinin geliştirilmesi bir uygulama. Akademik Bakış Dergisi, 35.

Taş, A. (2009). Ortaöğretim okulu müdürlerinin değişimi yönetme davranışlarına ilişkin öğretmen algılarının değerlendirilmesi. İn̈̈ü Üniversitesi Eğitim Fakültesi Dergisi, 10( 2), 1-18.

Taşkın, F. \& Dilek, R. (2010). Örgütsel güven ve örgütsel bağlılık üzerine bir alan araştırması. Organizasyon ve Yönetim Bilimleri Dergisi, 2(1), 37-46. 
Tokgöz, E. \& Seymen, O.A. (2013). Örgütsel güven, örgütsel özdeşleşme ve örgütsel vatandaşlik davranış1 arasındaki ilişki. Marmara Üniversitesi Sosyal Bilimler Enstitüsü Dergisi, 10(39), 61-76.

Top, M. (2012).Hekim ve hemşirelerde örgütsel bağlılık, örgütsel güven ve iş doyumu profili. Istanbul Üniversitesi Işletme Fakültesi Dergisi, 41(2), 258-277.

Tschannen-Moran, M. (2009). Fostering teacher professionalism in schools, the role of leadership orientation and trust. Educational Administration Quarterly, 45 (2), 217-247.

Tschannen-Moran, M. (2001). Collaboration and the need for trust. Journal of Educational Administration, 39(4), 308-331.

Turhan, M., Köprülü, O. \& Helvacı, İ. (2018). Örgütsel güven ile bireysel iş performansı arasındaki ilişki.

Türker, Y. \& Çelik, K. (2018). Öğretmenlerde iş ve aile çatışmasının yaşam doyumu üzerindeki etkisinde iş doyumunun arac1 rolü. Hacettepe Üniversitesi Eğitim Fakültesi Dergisi, 34(1), 242-258.

Tüzün, İ.K. (2007). Örgütsel güven ve örgütsel güven modelleri. Karamanoğlu Mehmetbey İ.I.B.F Dergisi, 13 (2), 93-118.

Usikalu, O., Ogunleye, A. \& Effion, J. (2015). Organisational trust, job satisfaction and performance among teachers in Eketi state, Nigeria. British Open Journal of Psychology, 1(1), 1-10.

Vakola, M., Tsaousis, I. \& Nikolaou, I. (2004). The role of emotional intelligence and personality variables on attitudes toward organisational change. Journal of Managerial Psychology, 19(2), $88-110$.

Vakola, M. \& Nikolaou, I. (2005). Attitudes towards organizational change: What is the role of employees' Stress and commitment?. Employee Relations, 27(2), 160 - 174.

Vandeyar, S. (2017). The teacher as an agent of meaningful educational change. Educational Sciences Theory and Practice, 17(2), 373-393.

Van Wagoner, R. J. (2004). Influencing the perception of organizational change in community colleges. Community College Journal of Research and Practice, 28, 715-727.

Walker, H. J., Armenakis, A. A. \& Bernerth, J. B. (2007). Factors influencing organizational change efforts, Journal of Organizational Change Management, 20(6), 761 - 773.

Wang, Y., Tsai, Y. \& Lin, C. (2013). Modeling the relationship between perceived corporate citizenship and organizational commitment considering organizational trust as a moderator. Business Ethics: A European Review, 22(2), 218-233.

Whitener, E. M., Brodt, S. E., Korsgaard, M. A. \& Werner, J. M. (1998). Managers as initiators of trust: An exchange relationship framework for understanding managerial trustworthy behavior. The Academy of Management Review, 23(3), 513-530.

Yılmaz, K. (2009). Özel dershane öğretmenlerinin örgütsel güven düzeyleri ile örgütsel vatandaşlık davranışları arasındaki ilişki. Kuram ve Uygulamada Ĕ̈itim Yönetimi, 15(59), 471-490.

Yıldız, K. (2013). Öğretmenlerin örgütsel adalet ve örgütsel güven algıları. Sosyal Bilimler Enstitüsü Dergisi, 13(1), 289-316.

Yücel, C. \& Samancı, G. (2009). Örgütsel güven ve örgütsel vatandaşlık davranış1. Fırat Üniversitesi Sosyal Bilimler Dergisi, 19(1) 113-132. 